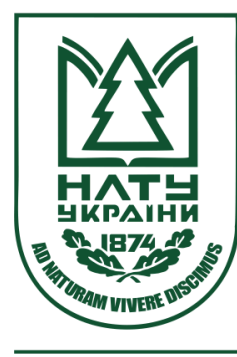

Науковий вісник НЛТУ України Scientific Bulletin of UNFU

https://nv.nltu.edu.ua

https://doi.org/10.15421/40290202

$@ \bowtie$ Correspondence author

Article received 28.02.2019 p.

Ye. Yo. Ripetskyi

Article accepted 28.03.2019 p.

erip@i.ua

УДК 528.[88+4]

Є. Й. Ріпецький, Р. Й. Ріпецький, Л. І. Дорош

Івано-Франківський національний технічний університет нафти і газу, м. Івано-Франківськ, Україна

\title{
ОБЛІК ЗМІНИ ПЛОЩ ЛІСОВИХ УГІДЬ У СТРУКТУРІ ЗЕМЕЛЬНОГО ФОНДУ ЗА ХАРАКТЕРИСТИКАМИ СУПУТНИКОВОГО ЗНІМКА
}

На прикладі гірського агроландшафтного середовища показано застосування технології дистанційного зондування Землі (Д33) до контролю зміни площ лісових угідь через їх вирубування. На підставі супутникового знімка QuickBird здійснено моделювання вирубок лісових угідь і отримано зображення територій з різними зонами вирубок. Зміни у структурі площ лісових угідь відбувається способом переміщення лінії розмежування "лісовий покрив - вирубка", за якого площі з лісового покриву переходять до зони вирубок. Доведено, що гістограмні характеристики RGB супутникового знімка QuickBird мають інформативність про зміни площ у структурі "лісовий покрив - вирубка". Показано, що величини медіан усіх RGB-каналів однозначно реагують на зміни площ лісового покрову. Найбільш чутливим до динаміки зміни площ 3 усіх RGB-каналів $\epsilon$ канал Green. Фізичне пояснення цього процесу здійснено на підставі тестових фрагментів "лісовий покрив" і "вирубка". Встановлено, що завдяки різній текстурі "лісового покрову" і "вирубки" їні гістограмні характеристики відрізняються зонами розміщення пікселів за яскравістю. Для фрагменту "лісовий покрив" основна частина пікселів у гістограмі зосереджена в діапазоні з кодом 0-100, тоді як для фрагменту "вирубка" вона зміщується вправо до діапазону 100-200. Більш однорідна текстура вирубок дає СКВ 24, що створює графік із чітко виразним екстремумом, який стає дедалі помітнішим із поширенням площі вирубок. Отримано аналітичну залежність між динамікою зміни площ $\Delta S$ на границі "лісовий покрив вирубка" і кількості пікселів $N_{\text {екстр }}$, що припадає на екстремум за кількістю пікселів у діапазоні гістограми 100-200. Показано їі достатньо високу чутливість, що дає змогу вирішувати задачі обліку зміни площ лісових угідь у структурі земельного фонду за характеристиками супутникового знімка.

Ключові слова: супутниковий знімок; агроландшафт; площа лісового покриву; гістограмні характеристики; RGB-канали.

Вступ. Зменшення площ лісових угідь через їх вирубки сьогодні стає однією з найбільш актуальних тем. Зупинити цю тенденцію можливо під час раціональної організації ведення лісового господарства на державному рівні, а це потребує оперативного контролю за станом лісів. Для цього залучають технології дистанційного зондування Землі (ДЗ3), які є невід'ємною частиною досліджень стану й динаміки лісового покриву (Vyshniakov \& Hrushyn, 2017). Власне на супутникових знімках чітко фіксуються в динаміці зменшення площі українських лісів з одночасною появою нових зон вирубок.

Нові підходи до обліку лісових угідь відкриваються 3 появою супутникових знімків QuickBird 3 високою роздільною здатністю до 0,6 м (Truskavetskyi et al., 2013). Такі знімки охоплюють територію розміром 16,5×16,5 км, що відповідає площі 27225 га. Для зазначеної території в кадрі супутникових знімків будуть відображатися не тільки ліси, але й інші складові земельного фонду. Серед них - пасовища, рілля, забудовані території, дороги, річки, водні та інші об'єкти.

Супутникові знімки QuickBird дають змогу достатньо точно ідентифікувати земельні угіддя згідно 3 прийнятою структурою земельного фонду. А в умовах агроладшафтного середовища під час оцінювання впливу антропогенних чинників структуру земельних угідь зменшено до п'яти рангів і її використовують для розрахунку індексів антропогенного навантаження (Ripetskyi \& Heredzhuk, 2017). Така невелика кількість рангів повинна забезпечити можливість вирішити проблему оперативної та достовірної оцінки антропогенного навантаження на агроландшафти, зокрема в разі інтенсивних вирубок лісу.

Тому задачі ідентифікації лісових угідь у структурі земельного фонду відрізняються від задач лісової таксації. Зазначені земельні угіддя агроландшафтів достатньо сильно відрізняються текстурою на кольорових супутникових знімках, що дає змогу проводити їхню ідентифікацію в режимі Truecolor (Myklush \& Havryliuk, 2006). Це тоді як лісова таксація проводиться в режимах "Treecover" або "Forest cover" (Myroniuk \& Bilous, 2017).

Однак задача полягає не тільки в тому, щоб ідентифікувати зони вирубок, але й надати механізм оперативного обліку та кількісної оцінки динаміки зміни площ лісових угідь через їх вирубування. Це допоможе фіксувати вирубки лісів ще на початкових стадіях і на-

\section{Інформація про авторів:}

Ріпецький Євгеній Йосипович, д-р техн. наук, професор, кафедра геодезії та землеустрою. Email: erip@i.ua

Ріпецький Роман Йосипович, канд. техн. наук, доцент, кафедра вищої математики. Email: romrip@i.ua

Дорош Любов Ігорівна, аспірант, кафедра геодезії та землеустрою. Email: liubov.dorosh@gmail.com

Цитування за ДСтУ: Ріпецький Є. Й., Ріпецький Р. Й., Дорош Л. І. Облік зміни площ лісових угідь у структурі земельного фонду за характеристиками супутникового знімка. Науковий вісник НЛтУ України. 2019, т. 29, № 2. С. 15-19.

Citation APA: Ripetskyi, Ye. Yo., Ripetskyi, R. Yo., \& Dorosh, L. I. (2019). Recording the change of forest land areas in the land resources structure using the characteristics of satellite imagery. Scientific Bulletin of UNFU, 29(2), 15-19. https://doi.org/10.15421/40290202 
давати необхідну інформацію в місцеві органи для іï припинення.

Аналіз останніх досліджень. Використання космічних знімків як засобу отримання інформації для визначення площ земельних угідь розглянуто в роботах (Myroniuk \& Bilous, 2017; Burak \& Dorosh, 2015; Barladin \& Yaroshchuk, 2006; Horshenyn, Puleko \& Chumakevych, 2013; Sulymko \& Shuvar, 2012).

Найбільш відповідальним методом оброблення космічних зображень у методиці визначення площ $\epsilon$ дешифрування супутникових знімків. Дешифрування спрямоване на виявлення за яскравістю пікселів земельних угідь, визначення їх контурів, тобто віднесення до певної категорії. Завдяки розвитку комп'ютерних технологій супутникові знімки дедалі більше дешифруються в автоматичному режимі (Horshenyn, Puleko \& Chumakevych, 2013).

На етапі дешифрування використовують різні методи покращення зображень. Наприклад, отримання бінарних зображень зелених насаджень дає змогу чітко виділити контури зелених насаджень, що зручно для операції векторизування (Sulymko \& Shuvar, 2012).

Прив'язаний супутниковий знімок до території дає змогу розробити векторну карту, за якою можна оцінити кількісний склад відзнятій території. Підвищення точності визначення площ земельних ділянок досягають операцією трансформування 3 використанням даних польових вимірів довжин ліній (Truskavetskyi et al., 2013).

Інший підхід до визначення кількісних показників безпосередньо за підрахунком пікселів різної яскравості пропонують методики з використанням багатоспектральних супутникових знімків, що отримуються знімальними системами в різних діапазонах частот (Burshtynska \& Stankevych, 2013).

Підрахунки кількості пікселів за яскравістю використовують під час визначення площ зелених насаджень. Для цього порівнюють характеристики багатоспектральних супутникових знімків за показником DOP (Myroniuk \& Bilous, 2017). Іншим способом використання яскравостей пікселів супутникових $\epsilon$ визначення урожайності біомаси за показником NDVI (Kokhan, 2012). Найчастіше використовують багатоспектральні супутникові знімки, отримані в інфрачервоному та червоному діапазонах. Ідея використання полягає в тому, що одні досліджувані явища чіткіше видно на різних діапазонах частот багатоспектральних знімків.

Однак скористатися багатоспектральними супутниковими знімками може лише обмежене коло фахівців. Більш доступними є власне кольорові супутникові знімки, які розміщені на різних порталах і є у вільному доступі. Тому розроблення методів визначення площ земельного фонду агроландшафтів за кількістю пікселів кольорового супутникового знімка $\epsilon$ актуальною. Це дасть змогу відмовитися від операцій з визначення контуру угідь, і здійснити безпосередньо підрахунок кількості пікселів, що припадає на кожне угіддя, враховуючи їхні яскравості.

У такому випадку кольоровий супутниковий знімок виступає як растрове зображення в режимі Truecolor. Основними характеристиками супутникового знімка будуть канали RGB, кожен з яких несе інформативність про склад угідь (Myklush \& Havryliuk, 2006).
Водночас інформативність каналів RGB кольорового супутникового знімка допомагає сформувати гіпотезу про можливість визначення площ земельних угідь за яскравістю пікселів. Найбільш актуальним напрямом досліджень є визначення зміни структури лісових угідь за їх площею по лінії розмежування "лісовий покрив вирубка".

Мета дослідження - на підставі моделювання зміни площ лісових угідь у структурі земельного фонду встановити показники функціонального зв'язку між гістограмними характеристиками RGB супутникового знімка i зміною площі по лінії "лісовий покрив - вирубка".

Матеріали і методи дослідження. Матеріалами дослідження є супутниковий знімок QuickBird з високою роздільною здатністю гірської території з лісовим покривом та іншими земельними угіддями. Методи дослідження - гістограмні характеристики супутникового знімка за RGB каналами, методи моделювання зображень зі змінами границь "лісовий покрив - вирубка".

Викладення основного матеріалу дослідження. У дослідженнях використано фрагмент 24-бітного кольорового супутникового знімка гірського регіону площею 90 га. Обраний фрагмент є агроладшафтним середовищем і відображає основні п'ять груп зазначених вище земельних угідь. Прив'язаний супутниковий знімок до території, згідно з методикою (Burak \& Dorosh, 2015), дав змогу встановити таку структуру земельного фонду: лісові угіддя, рілля, прибудинкові території, водні об'єкти та дороги на зазначеній території (рис. 1,a) у процентному відношенні становили 78:11:7,5:1:0,5 \%.
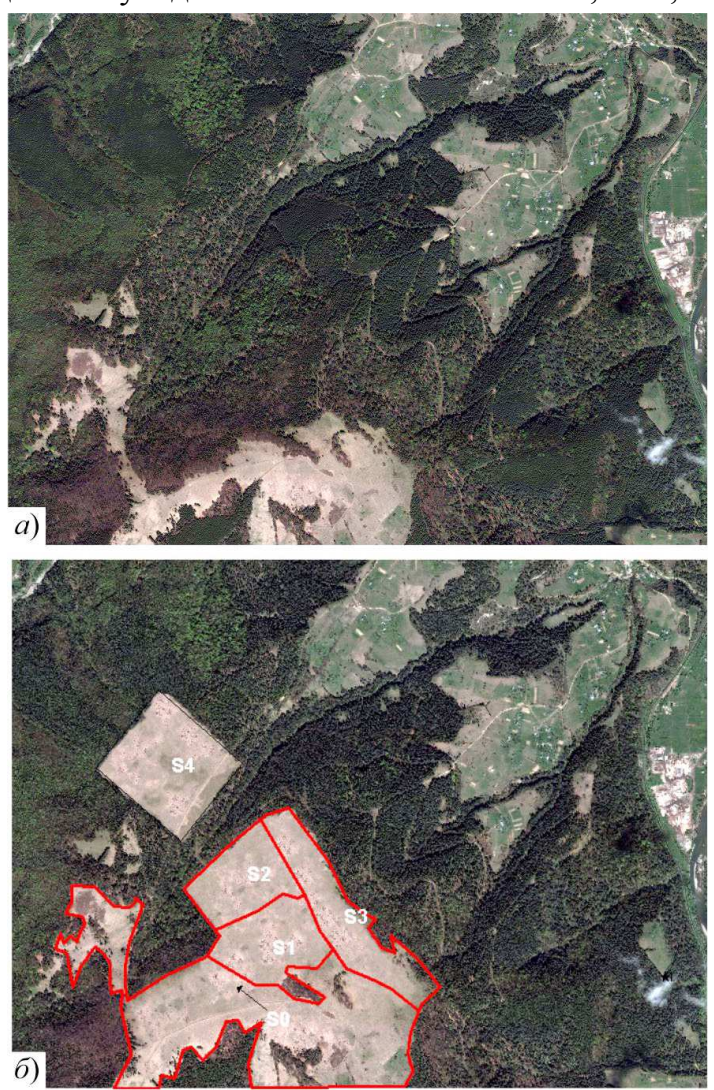

Рис. 1. Моделювання зон вирубок на фрагменті супутникового знімка QuickBird: a) лісові угіддя у структурі агроландшафтів; б) границі змодельованих зон вирубок

Такі об'єкти дослідження, як "лісовий покрив" та зони "вирубки", були чітко помітні на супутниковому знімку. Це дало змогу провести між ними границю, яка відігравала роль початкової лінії розмежування. На цій 


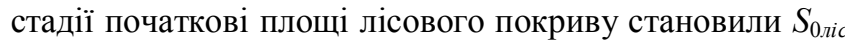
$=64,85$ га, а зони вирубки $-S_{0 в и р}=5,41$ га.

На обраному фрагменті супутникового знімка засобами моделювання були створені додаткові зони вирубок. Моделювання нових зон вирубки на супутниковому знімку було зроблено у програмі Photoshop. Характерний фрагмент зон вирубок був поширений на супутниковому знімку, замінюючи території з лісовим покривом. Змодельовані в такий спосіб зони вирубок зображено на рис. 1,б. На рисунку видно початкові границі лінії "лісовий покрив - вирубка" і додатково чотири фрагменти 3 відповідними площами вирубок: $S_{1}=$ $12820,5 \mathrm{~m}^{2} ; \quad S_{2}=11136,63 \mathrm{~m}^{2} ; \quad S_{3}=15644,92 \mathrm{~m}^{2} ; \quad S_{4}=$ $18493,37 \mathrm{~m}^{2}$. Отже, було отримано додаткові чотири фрагменти з різними площами зон вирубок.Далі для супутникового знімка й отриманих чотирьох фрагментів визначали гістограмні характеристики за каналами RGB. Для цього використали програму DIPEit, яка призначена для підтримки комп'ютерних технологій Д33. Приклад гістограмних характеристик RGB за каналом Green для території на супутниковому знімку наведено на рис. 2. Вони відображають частотність розподілу кількості пікселів за яскравістю, яка визначається кодом кольору зі значенням від 0 до 255. Статичними характеристиками будуть середнє значення, середнє квадратичне відхилення (СКВ) і медіана.

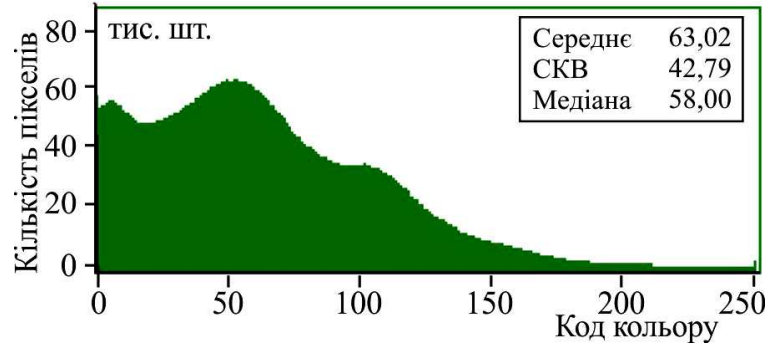

Рис. 2. Гістограмні та статистичні характеристики каналу Green зображення території на супутниковому знімку QuickBird за даними програми DIPEdit

Дані гістограмних характеристик як початкового супутникового знімка, так і змодельованих територій наведено в табл. 1 для каналу Luminosity і ще трьох каналів RGB: Red, Green i Blue.

Табл. 1. Значення медіани за каналами RGB для супутникового знімка під час моделювання зміни площ "лісовий покрив - вирубка"

\begin{tabular}{|c|c|c|c|c|c|}
\hline \multirow{2}{*}{ Знімок } & $\begin{array}{c}\text { Динаміка } \\
\text { площі угідь, } \\
\text { м }^{2}\end{array}$ & $\begin{array}{c}\text { Статистичний показник каналів } \\
\text { Lumi- } \\
\text { nosity }\end{array}$ & Red & Green & Blue \\
\hline $\begin{array}{c}\text { Супутниковий } \\
\text { знімок }\end{array}$ & 0 & 55 & 55 & 58 & 53 \\
\hline Модель 1 & 12820,5 & 58 & 57 & 61 & 56 \\
\hline Модель 2 & 23957,13 & 59 & 58 & 62 & 57 \\
\hline Модель 3 & 39602,05 & 61 & 60 & 64 & 59 \\
\hline Модель 4 & 58095,42 & 63 & 62 & 67 & 61 \\
\hline & $\Delta S=58095,42$ & $\Delta=8$ & $\Delta=7$ & $\Delta=9$ & $\Delta=8$ \\
\hline $\begin{array}{c}\text { Чутливість, } \Delta / \Delta S \cdot 10^{-3}, \\
\text { пікс./ }{ }^{2}\end{array}$ & 0,137705 & 0,137705 & 0,154919 & 0,137705 \\
\hline
\end{tabular}

3 ростом площі зон вирубок змінюється спектр гістограм, що фіксується медіаною. Цим самим підтверджуємо можливість дослідження динаміки зміни площ у структурі лісових угідь по лінії "лісовий покрив - вирубка". Хоча отримані значення чутливості в край низькі, все ж можна стверджувати, що в гістограмних характеристиках супутникових знімків закладена інформативність про зміни площ у структурі угідь.
Найбільш чутливим до зміни динаміки площ 3 усіх RGB каналів є канал Green 3 чутливістю 0,154919·10 ${ }^{-3}$ пікс./м². Однак усереднені статистичні показники, наприклад значення медіани, через низьку чутливість не дають змогу вирішувати задачі обліку площ вирубок. Для цього необхідно перейти до аналізу самих графіків гістограм (див. рис. 2). Тому в подальших дослідженнях зосередимося лише на каналі Green 3 метою підняття чутливості до величини, здатної аналізувати зміни площ у структурі угідь.

На рис. 3 зображено зведені гістограмні характеристики за каналом Green для різних випадків у разі зміни величини площі, а саме перенесенням їх від категорії "лісовий покрив" до категорії "вирубки". Початковий стан угідь на графіку відображає крива $a$, яку назвемо еталонною. Для еталонної кривої функціональну залежність кількості пікселів від величини коду кольору позначимо як $F(k o d)$. Інші чотири криві 1-4 (див. рис. 3), які відповідають змодельованим зонам вирубок (від $\Delta S_{1}=12820,5 \mathrm{~m}^{2}$ до $\left.\Delta S_{4}=58095,42 \mathrm{~m}^{2}\right)$, подамо у вигляді $f_{i}$ (kod), де $i=1-4$.

Всі зміни у структурі угідь будемо порівнювати 3 еталонною кривою - $a$. На графіку рис. 3 видно, що зі зменшенням площі лісового покриву й одночасним збільшенням площі вирубки (криві 1-4) спостерігаємо зниження кількості пікселів за яскравістю від 0 до 100 i, навпаки, підвищення їх кількості в діапазоні 120-200.

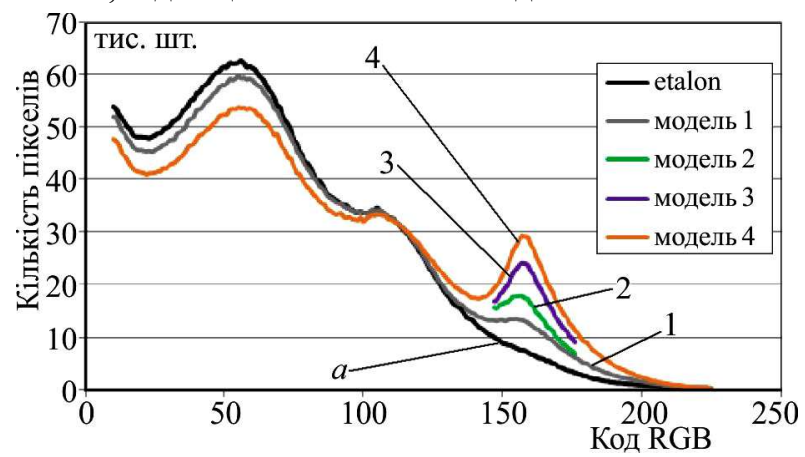

Рис. 3. Зведені гістограмні характеристики за каналом Green під час моделювання зон вирубок

Для пояснення цього явища на супутниковому знімку було обрано тестові фрагменти окремих ділянок "лісового покриву" та "вирубки" і отримано їхні гістограмні характеристики (рис. 4).
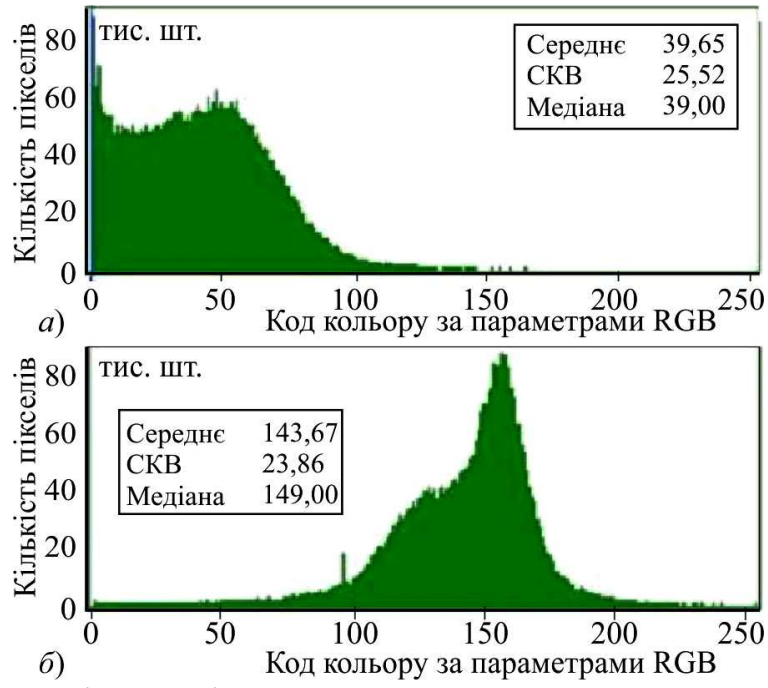

Рис. 4. Гістограмні характеристики за каналом Green тестових фрагментів: а) "лісового покриву"; б) "вирубки" 
На підставі порівнянь характеристик двох гістограм (рис. 4,a,б) видно, що для фрагменту "лісового покриву" основна кількість пікселів зосереджена в лівій частині спектра 3 кодом кольору від 0 до 100, а для зон вирубок спектр зміщується вправо до діапазону 120-200 3 появою чітко вираженого екстремуму-максимуму. Відповідно медіани гістограм будуть для "лісового покриву" - 39; а для "вирубки" - 149.

Різницю в характері гістограмних графіків (див. рис. $4, a, \sigma)$ пояснюємо тим, що зони вирубок мають більш однорідну текстуру, тому іiі СКВ розподілу яскравості пікселів у гістограмі буде меншим, що призводить до витягнутого графіка з появою чіткого екстремуму. Натомість текстура лісового покриву більш різноманітна. На знімку можна виділити окремі дерева, їх різне освітлення, зони просік та ін. Тому графік лісового покриву розтягнутий, хоча й екстремум присутній, але він не $є$ таким чітким.

Повертаючись до рис. 3, зрозуміло причини появи піків у діапазоні 100-200 та їхній ріст у разі збільшення площі вирубок. Спробуємо на підставі отриманих піків правої частини графіка, які є характерними для зон вирубок, встановити кореляційну залежність між площею вирубок і характеристиками супутникового знімка за значеннями величин екстремумів.

Для цього на підставі гістограмних характеристик (див. рис. 3) побудуємо нові графіки відхилень кривих 1-4, що відображають різні площі вирубок, від еталонної кривої $a$ (рис. 5). Тобто фунціонал кривих 1-4 буде мати такий вигляд:

$$
\Phi_{i}(k o d)=F(k o d)-f_{i}(k o d) .
$$

Графіки функціонала (1) чотирьох змодельованих територій наведено на рис. 5. На лівій частині графіка в діапазоні від 0 до 100 поведінку кривих 1-4 лімітують характеристики "лісового покриву". Власне вони й переважають у спектральних характеристиках рис. 3. Усі чотири криві знаходяться у зоні від'ємних значень, що свідчить про поступове зменшення площ "лісового покриву". I навпаки - в діапазоні від 100 до 200 криві приймають додатні значення 3 чітко вираженими піками екстремумів. Це знов-таки узгоджується 3 гістограмними характеристиками тестової ділянки зони вирубки i дає змогу однозначно зрозуміти, що площі вирубок збільшуються від кривої 1 до кривої 4.

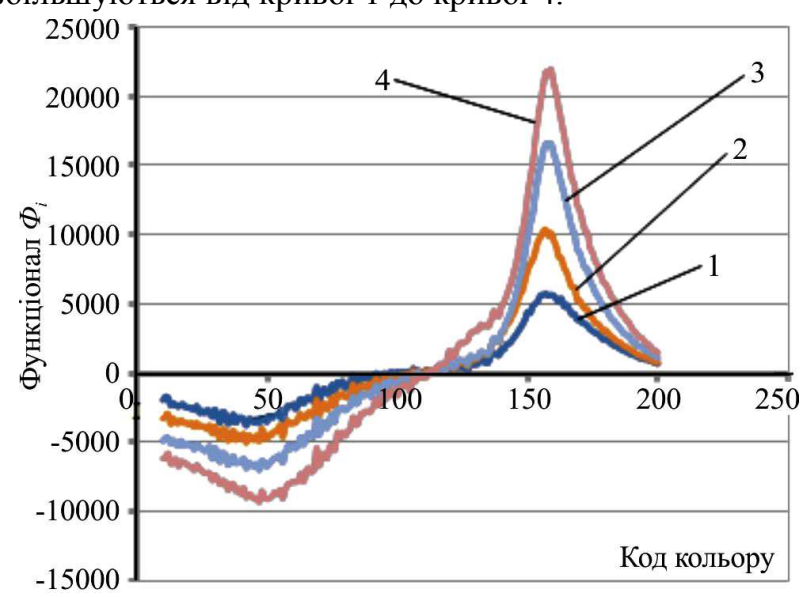

Рис. 5. Графіки відхилення розподілу яскравості пікселів $\left(\Phi_{i}\right)$ від початкової еталонної кривої зі збільшенням зони вирубок (та зменшенням лісового покриву)

Оскільки зміна площі угідь відбувалася переходом площі $\Delta S_{i}$ від категорії "лісовий покрив" до категорії "вирубка", а інші угіддя були незмінними за умовою моделювання, тому для всіх кривих графіка рис. 5 справедлива рівність

$$
\int_{0}^{255} \Phi_{i}(k o d) d k o d=0 .
$$

На підставі графіків (див. рис. 5) отримано таблицю кореляційної залежності між зміною площ та екстремумами яскравостей зони 100-200 для кривих 1-4.

Табл. 2. Кореляційна залежність між зміною площ вирубок $\Delta \mathrm{S}$ та екстремумами $N_{\text {екстр }}$ функціоналу $\Phi_{\mathrm{i}}$

\begin{tabular}{|c|c|c|}
\hline Знімок & \begin{tabular}{|c|} 
3міна площ, \\
$\Delta S \mathrm{~m}^{2}$ \\
\end{tabular} & $\begin{array}{l}\text { Екстремуми гра- } \\
\text { фіків } 1-4, N_{\text {екстр }}\end{array}$ \\
\hline Супутниковий знімок & 0 & 0 \\
\hline Модель 1 & 12820,5 & 5750 \\
\hline Модель 2 & 23957,13 & 10375 \\
\hline Модель 3 & 39602,05 & 16623 \\
\hline Модель 4 & 58095,42 & 21979 \\
\hline \multicolumn{2}{|c|}{ Чутливість $N_{\text {екстр }} / \Delta S$, пікс. $/ \mathrm{m}^{2}$} & 0,378326 \\
\hline
\end{tabular}
графіків 1-4 за рис. 5

На рис. 6 зображено графік такої кореляційної залежності та встановлено аналітичний запис функціонального зв'язку між динамікою зміни площ $\Delta S$ на границі "лісовий покрив - вирубка" і кількості пікселів $N_{\text {екст }}$, що припадає на екстремум графіків (1-4): $\Delta S=2,7593 N_{\text {екст }}-4133,5$.

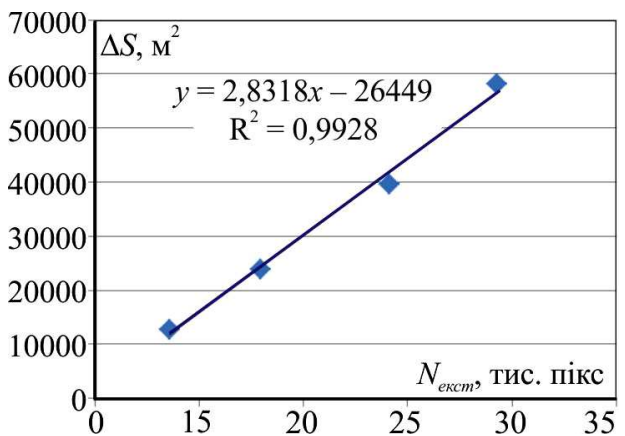

Рис. 6. Графік кореляційної залежності між зміною площ лісових угідь $\Delta \mathrm{S}$ по лінії "лісовий покрив - вирубка" та екстремальної кількості пікселів $N_{\text {екст }}$ функціоналу $\Phi_{\mathrm{i}}$

Отже, отримана функціональна залежність (3) свідчить про наявність у супутникових знімках інформативних ознак про динаміку зміни площ $\Delta S$ на границі "лісовий покрив - вирубка" і кількості пікселів, що припадає на екстремум функціоналу $\Phi_{i}$. Досягнута висока чутливість сигналів дає змогу вирішувати задачі обліку зміни площ лісових угідь у структурі земельного фонду за характеристиками супутникового знімка.

\section{Висновки:}

1. Гістограмні характеристики супутникового знімка QuickBird реагують на динаміку зміни площ лісових угідь по лінії "лісовий покрив - вирубка", про що свідчить зміна показника медіани для всіх каналів RGB. Найкращі показники надає канал Green. Однак отримана чутливість за статистичними показниками досить низька, що не дає змоги здійснювати облік земельних угідь лише за значенням медіани.

2. Гісторгамні характеристики окремих тестових фрагментів "лісовий покрив" та "вирубка" завдяки різній текстурі відрізняються зонами розміщення пікселів за яскравістю. У фрагменті "лісовий покрив" основна частина пікселів зосереджена в зоні 0-100, а для фрагмента "вирубка" - 100-200. Більш однорідна текстура вирубок зі СКВ 23,86 створює графіки з чітко виразним екстремумом. 
3. Отримано аналітичну залежність (3) між динамікою зміни площ $\Delta S$ на границі "лісовий покрив - вирубка" і кількістю пікселів $N_{\text {екст }}$, що припадає на екстремум запропонованого функціоналу, яка має достатню високу чутливість і дає змогу вирішувати задачі обліку зміни площ лісових угідь у структурі земельного фонду за характеристиками супутникового знімка.

\section{Перелік використаних джерел}

Barladin, O., \& Yaroshchuk, P. (2006). Vykorystannia kosmichnykh znimkiv QuickBird dlia stvorennia i onovlennia fotokarty velykoho mista (na prykladi Kyiv). Suchasni dosiahnennia heodezychnoi nauky ta vyrobnytstva, 1(11), 48-52. [In Ukrainian].

Burak, K. O., \& Dorosh, L. (2015). Doslidzhennia mozhlyvostei vykorystannia materialiv kosmoznimannia dlia vyznachennia ploshch. Suchasni dosiahnennia heodezychnoi nauky ta vyrobnytstva, 2(30), 48-52. [In Ukrainian].

Burshtynska, Kh., V., \& Stankevych, S. A. (2013). Aerokosmichni znimalni systemy. Lviv: Vyd-vo Lviv. Politekhniky, 315 p. [In Ukrainian].

Horshenyn, O. Ye., Puleko, I. V., \& Chumakevych, V. O. (2013). Osnovy obroblennia ta deshyfruvannia znimkiv z kosmichnoho aparata "Sich-2" dlia rozviazannia tematychnykh zadach lisovoho hospodarstva. Scientific Bulletin of UNFU, 23(15), 300-308. [In Ukrainian].

Kokhan, S. S. (2012). Zastosuvannia vehetatsiinykh indeksiv normalizovanoi riznytsi ta zvazhenoi riznytsi pry vyznachenni stanu silskohospodarskykh kultur. Dop. NAN Ukrainy, 2, 135-140. Retrieved from: $\quad$ http://dspace.nbuv.gov.ua/bitstream/handle/123456789/ 49025/21-okhan.pdf?sequence=1. [In Ukrainian].

Myklush, S. I., \& Havryliuk, S. A. (2006). Informatyvnist kanaliv kosmichnykh znimkiv Landsat-7 ETM+ dlia deshyfruvannia roslynnosti. Scientific Bulletin of UNFU, 16(7), 8-13. [In Ukrainian].

Myroniuk, V. V., \& Bilous, A. M. (2017). Uzhodzhenist otsinok ploshchi lisiv za danymy hlobalnoi karty zmin lisovoho pokryvu i multyspektralnykh suputnykovykh znimkiv. Scientific Bulletin of UNFU, 27(5), 38-42. [In Ukrainian].

Ripetskyi, Ye. Y., \& Heredzhuk, I. I. (2017). Vykorystannia HIStekhnolohii pry otsintsi antropohennoho tysku na ahrolandshafty $\mathrm{v}$ upravlinniakh mistsevoho rivnia. Tezy konferentsii Mizhnarodnoi naukovo-praktychnoi konferentsii "Ekoheoforum. Aktualni problemy ta innovatsii". Mart 22-25, 2017, (pp. 359-360). Ivano-Frankivsk. [In Ukrainian].

Sulymko, R. T., \& Shuvar, R. Ya. (2012). Vykorystannia danykh DZZ vysokoi rozdilnoi zdatnosti $\mathrm{v}$ heoinformatsiinykh systemakh. Naukovyi visnyk KUEITU Novi tekhnolohii, 4(38), 49-54. [In Ukrainian].

Truskavetskyi, R. S., Fedorak, V. I. (Eds.), Ripetskyi, Ye. Y., et al. (2013). Stratehiia zbalansovanoho zemlekorystuvannia na Prykarpatti. Chernivtsi: DrukArt, 240 p. [In Ukrainian].

Vyshniakov, V. Yu., \& Hrushyn, O. V. (2017). Monitorynh lisonasadzhen terytorii Ukrainy z vykorystanniam danykh DZZ. Aktualni problemy ta innovatsii: Materialy mizhnarodnoi naukovo-praktychnoi konferentsii "Ekoheoforum", (pp. 267-268). Ivano-Frankivsk. [In Ukrainian].

Ye. Yo. Ripetskyi, R. Yo. Ripetskyi, L. I. Dorosh

Ivano-Frankivsk National Technical University of Oil and Gas, Ivano-Frankivsk, Ukraine

\section{RECORDING THE CHANGE OF FOREST LAND AREAS IN THE LAND RESOURCES STRUCTURE USING THE CHARACTERISTICS OF SATELLITE IMAGERY}

Using the example of a mountainous cultivated land environment, we have shown the use of Earth Remote Sensing Data (ERS) technology to control the change of forest land area due to their being cut down. The footage of the Quick Bird satellite image has been used for a simulation of the change in the forest area structure from "forest land" to "deforestation" in which the forest land area shifts into the cut down (deforested) area. It is proved that the histogram characteristics of the RGB Quick Bird satellite image contain information on changes in forest land are structure from "forest land" to "deforestation". It is shown that the median size of the RGB histogram responds to the change in the area of the forest land. The most sensitive out of all RGB channels to changing area dynamics is the channel Green. Physical explanation of this process is carried out using the test fragments "forest land" and "deforestation". We have found out that due to the different texture of the "forest land" and "deforestation" images, their histogram characteristics, the zones of pixel placement, differ in brightness. In the fragment "forest land" the majority of pixels in the histogram is concentrated in the range of $0-100$, while for the fragment "deforestation" it shifts to the right to a range of 100-200. Mean square deviation (MSD) - 24 gives a more homogeneous texture of the deforestation, as it creates a graph with a clearly expressive extremum that becomes more and more visible as the cutting down spreads. An analytical dependence between the dynamics of the areas $\Delta S$ change at the boundary between "forest land" and "deforestation" and the number of pixels $\Delta N$ per the extremum, is obtained. Its considerably high sensitivity has been shown which allows solving the problems of recording the change of forest land areas in the land resource structure using the characteristics of satellite imagery.

Keywords: satellite imagery; cultivated land; forest land area; histogram characteristics; RGB-channels. 